\title{
Clonal reproduction of Azolla filiculoides Lam.: implications for invasiveness
}

\author{
Rocío Fernández-Zamudio,*, Santos Cirujano ${ }^{2}$, Salvador Sánchez-Carrillo ${ }^{3}$, Ana Meco ${ }^{2}$ and \\ Pablo García-Murillo ${ }^{1}$
}

${ }^{1}$ Department of Plant Biology and Ecology, Faculty of Pharmacy, University of Seville, C/ Profesor García González, 2, 41012 Seville, Spain.

2 Royal Botanical Garden, Madrid (CSIC), Plaza de Murillo 2, 28014 Madrid, Spain.

${ }^{3}$ National Museum of Natural Sciences (MNCN-CSIC), C/ José Gutierrez Abascal 228006 Madrid, Spain.

* Corresponding author: rzamudio@us.es

Received: 30/10/12

Accepted: 24/7/13

\begin{abstract}
Clonal reproduction of Azolla filiculoides Lam.: implications for invasiveness

Clonal reproduction of Azolla filiculoides Lam., an aquatic floating fern, native from the American subtropics and a recent invader of Mediterranean wetlands, was assessed experimentally. Shoot fragmentation of the species was quantified under suitable room conditions for optimum growth. Azolla fililculoides showed high longevity, a low mortality percentage and a high potential for clonal reproduction (biomass obtained by shoot fragmentation from only one individual was multiplied by 100). This last attribute changed over time: first generations developed a high number of propagules, a number which decreased progressively in later generations until the end of the experiment. The results of this experiment will be useful for understanding Azolla's success within invaded habitats.
\end{abstract}

Key words: Azolla, plant clonal reproduction, invasive species, Iberian Peninsula.

\section{RESUMEN}

Reproducción clonal de Azolla filiculoides Lam.: consecuencias para su éxito invasor

La reproducción vegetativa por fragmentación de Azolla filiculoides, helecho acuático propio de medios subtropicales americanos pero presente recientemente en medios acuáticos temporales, fue valorada experimentalmente. Se cuantificó la tasa de fragmentación de la especie en condiciones controladas y favorables para asegurar un crecimiento óptimo de la especie. Azolla filiculoides presentó una alta longevidad, una baja tasa de mortalidad y una alta capacidad de reproducción vegetativa por fragmentación (la biomasa obtenida a partir de un solo individuo se multiplicó por 100 durante la experiencia). Sin embargo la tasa de fragmentación no fue constante: las primeras generaciones generaron un número superior de propágulos que fue decreciendo exponencialmente en generaciones posteriores hasta el final de la experiencia. Los resultados obtenidos resultan útiles para entender el éxito de la colonización en medios invadidos.

Palabras clave: Azolla, reproducción clonal, especies invasoras, Península Ibérica.

\section{INTRODUCTION}

Perennial plants usually combine sexual reproduction by seeding with clonal reproduction through vegetative propagation (Eckert et al., 2003). In most aquatic angiosperm taxa, asexual modes of reproduction are dominant over sexual modes (Barret et al., 1993; Grace, 1993; Garbey 
et al., 2004; Xiao et al., 2007). Asexual modes are usually induced by adverse environmental conditions or by a lack of resource availability, inhibiting normal life cycle (Barret et al., 1993; Honnay \& Bossuyt, 2005). Among invasive species, almost $60 \%$ are clonal, which suggests that clonal growth may be associated with invasiveness (Alpert et al., 2000; Kolar \& Lodge, 2001). In this context, vegetative propagation is not only understood as a way of ensuring the survival of populations but also as a great opportunity for rapid and efficient dispersion and new habitat colonisation (Sculthorpe, 1967).

One of the most common methods of clonal reproduction in submerged and free-floating flora is shoot fragmentation (Wetzel, 2005). Detaching fragments function as new individuals with the ability to photosynthesise, uptake nutrients from the water column, multiply, and disperse using water as an efficient vector (Grace, 1993).

Azolla filiculoides Lam. (Azollaceae, hereafter $\mathrm{AF}$ ) is a small floating fern and native from the American subtropics (Landolt, 1999; Galán de Mera et al., 2006). It is broadly distributed in aquatic ecosystems all over the world and is considered in some parts to be an invasive species (Sheppard et al., 2006). It reproduces asexually via shoot fragmentation, an ability that ensures a high increase of populations in the absence of environmental constraints (Wagner, 1997).

The aim of this work is to assess the clonal reproduction model of AF, by studying shoot fragmentation rates of individuals growing in the absence of environmental constraints. For this purpose, individuals of AF were obtained from spores found in Doñana National Park (SO Spain). This area, a Ramsar wetland well-known for its conservation value (García-Novo \& Marín, 2006), has been recently colonised by AF (García-Murillo et al., 2007).

\section{MATERIAL AND METHODS}

\section{Experimental design}

Owing to the impossibility of running this experiment in the field, we decided to work under labo-

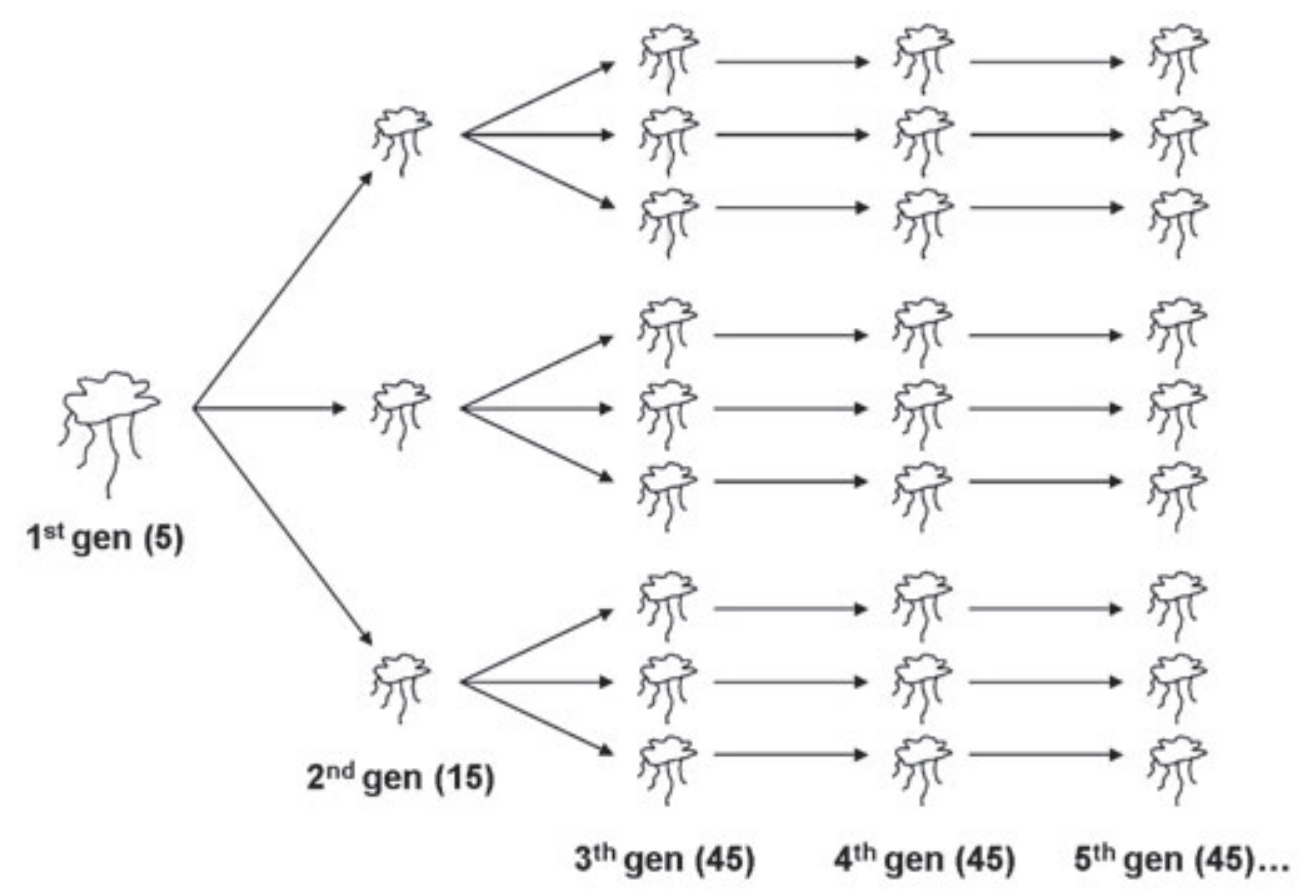

Figure 1. Selection procedure of propagules included in the experimental design from mother-plants. Resumen de la selección de propágulos a partir de las planta-madre para ser incluidos en el diseño experimental. 
ratory conditions, similarly to how other physiological experiments with Azolla (Cary \& Weerts, 1992; Janes et al., 1996; Rai et al., 2006) have been developed.

We chose five just-germinated individuals of AF (hereafter referred to as mother-plants) which were measured and weighed before the beginning of the experiment. The individuals were placed in separate holes in plastic seedbeds under greenhouse conditions [regime of $12 \mathrm{~h}$ of light (mean maximum temperature $37.6^{\circ} \mathrm{C}$, 400$700 \mathrm{~nm}, 35 \mu \mathrm{mol}$ photons $\mathrm{m}^{-2} \mathrm{~s}^{-1}$ ) and $12 \mathrm{~h}$ of darkness (mean minimum temperature $17.9^{\circ} \mathrm{C}$ )] to ensure optimum growth. The individuals were submerged in trays filled with $1 \mathrm{~cm}$ of standard compost (sand+peat+humus) and 101 of water (salinity in a range of $700-1000 \mu \mathrm{S} \mathrm{cm}^{-1}$ and $\mathrm{pH}$ of approximately 7.5). Water was supplemented with sodium monophosphate to reach an optimal concentration of dissolved phosphorus (1.5 mg $1^{-1}$ ) for the AF survival (Cirujano et al., 2008). Culture media was replaced every week to ensure phosphorus availability.

From each of the initial five mother-plants, three new propagules obtained via shoot fragmentation were selected to be incorporated into the experiment (second generation). For the third generation, three new propagules were selected from each of the fifteen individuals, resulting in sixty individuals placed in the fourth generation; from the $4^{\text {th }}$ through the $11^{\text {th }}$ generations, only one propagule from each individual was selected and incorporated into the experiment (Fig. 1). The remaining individuals of every generation were discarded after being counted.

In the end, the shoot fragmentation of 324 individuals were followed weekly over 215 days, to calculate the total number of propagules per generation, the maximum number of propagules per individual, the fragmentation rate (number of propagules per day) and the mortality rate (number of dead individuals per day).

\section{Data analyses}

The differences between generations in the total number of propagules, the fragmentation rate and the maximum number of propagules per in- dividual, were analysed through one-way analysis of variance (ANOVA) followed by a Tukey post hoc test. The significance level $(p)$ considered throughout the experiment was 0.05 and the analyses were carried out with the software Statistica v.6 (Statsoft, 2001).

The increase in biomass through time was estimated from the initial biomass values measured from the mother-plants and the fragmentation rate data obtained from the experiment. The results were fitted to a non-linear (sigmoidal) function that permitted us to assess the potential biomass per capita rate over time. Curve fitting was carried out with CurveExpert v.1.4.

\section{RESULTS}

The mean initial length of the mother-plants was $7 \mathrm{~mm}$ (length) $\times 2 \mathrm{~mm}$ (width), with an initial fresh biomass of $0.0044 \pm 0.0025 \mathrm{~g}$ (mean $\pm \mathrm{SE})$. The total number of propagules per generation was $15.05 \pm 2.18$ (mean $\pm \mathrm{SE})$. None of the mother-plants died during the experiment; however, some of the individuals produced by shoot fragmentation died. The mortality rate for these individuals was $1.60 \pm 0.71 \%$ (mean $\pm \mathrm{SE}$ ). There were no sexual structures observed during the experiment.

The total number of propagules per generation showed significant differences between generations $\left(F_{10,313}=34.116 ; p=0.0001\right)$. First generations developed a high number of propagules, a number which decreased progressively in later generations $[45.60 \pm 11.19$ and $0.50 \pm 0.27$ in the $1^{\text {st }}$ and $11^{\text {th }}$ generation, respectively (Table 1$)$ ]. The maximum number of propagules per individual followed the same pattern $\left[\left(F_{10,313}=21.954\right.\right.$; $p=0.000), 7.80 \pm 1.36$ and $0.40 \pm 0.22$ in $1^{\text {st }}$ and $11^{\text {th }}$ generation, respectively (Table 1)]. The fragmentation rate also varied significantly between generations $\left(F_{10,313}=34.116 ; p=0.0001\right)$, decreasing exponentially (Fig. 2).

The temporal increase in biomass was fitted to a sigmoidal function $(r=0.998 ; \mathrm{SE}=0.01$, Fig. 3). Applying this function, an individual with an initial biomass of $0.0044 \pm 0.0025 \mathrm{~g}$ $(n=5)$, would through shoot fragmentation and 
Table 1. Mean number of propagules, maximum number of propagules and fragmentation rate of Azolla filiculoides between generations (mean $\pm \mathrm{SE}$ ). Evolución temporal del número medio de vástagos producidos por plantas-madre de Azolla filiculoides representativas de cada generación (media $\pm S E$ ).

\begin{tabular}{|c|c|c|c|}
\hline Generation $(N)$ & $\begin{array}{c}\text { Total Mean } \\
\mathrm{N}^{\mathrm{o}} \text { Propagules }\end{array}$ & Fragmentation Rate & $\begin{array}{c}\text { Maximum } \\
\mathrm{N}^{\mathrm{o}} \text { Propagules/ind }\end{array}$ \\
\hline $1(5)$ & $45.60 \pm 11.19$ & $0.21 \pm 0.05$ & $7.80 \pm 1.36$ \\
\hline $2(15)$ & $33.47 \pm 4.16$ & $0.16 \pm 0.02$ & $6.60 \pm 0.94$ \\
\hline $3(45)$ & $21.84 \pm 1.72$ & $0.10 \pm 0.01$ & $4.49 \pm 0.41$ \\
\hline $4(45)$ & $17.40 \pm 1.28$ & $0.08 \pm 0.01$ & $3.84 \pm 0.31$ \\
\hline $5(45)$ & $13.93 \pm 1.18$ & $0.06 \pm 0.01$ & $3.04 \pm 0.25$ \\
\hline $6(43)$ & $11.06 \pm 1.01$ & $0.05 \pm 0.00$ & $2.72 \pm 0.25$ \\
\hline 7 (39) & $11.05 \pm 1.06$ & $0.05 \pm 0.00$ & $2.51 \pm 0.19$ \\
\hline $8(24)$ & $6.18 \pm 1.01$ & $0.03 \pm 0.00$ & $1.76 \pm 0.22$ \\
\hline $9(27)$ & $2.63 \pm 0.57$ & $0.01 \pm 0.00$ & $1.07 \pm 0.21$ \\
\hline $10(16)$ & $1.87 \pm 0.57$ & $0.01 \pm 0.00$ & $1.12 \pm 0.24$ \\
\hline $11(10)$ & $0.50 \pm 0.27$ & $0.00 \pm 0.00$ & $0.40 \pm 0.22$ \\
\hline
\end{tabular}

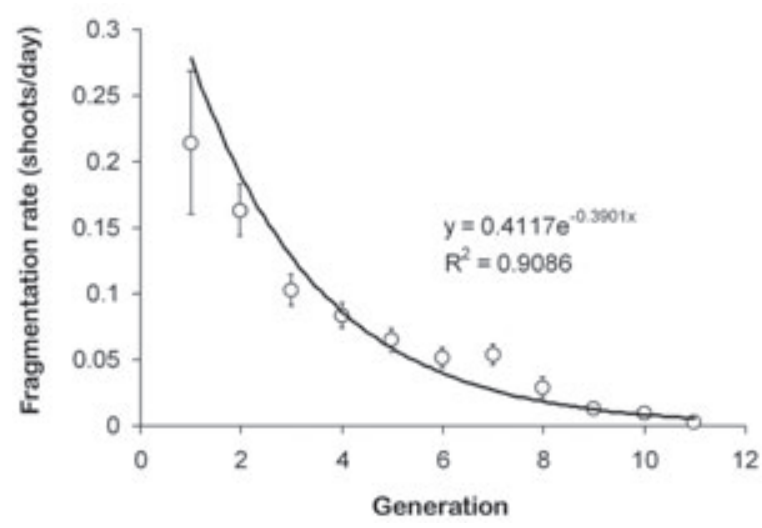

Figure 2. Mean $\pm \mathrm{SE}$ values for the fragmentation rate as fitted along generations of Azolla filiculoides $(p<0.05)$. Ajuste de los valores medios $\pm S E$ de las tasas de fragmentación obtenidas de los individuos de Azolla filiculoides representativos de cada generación.

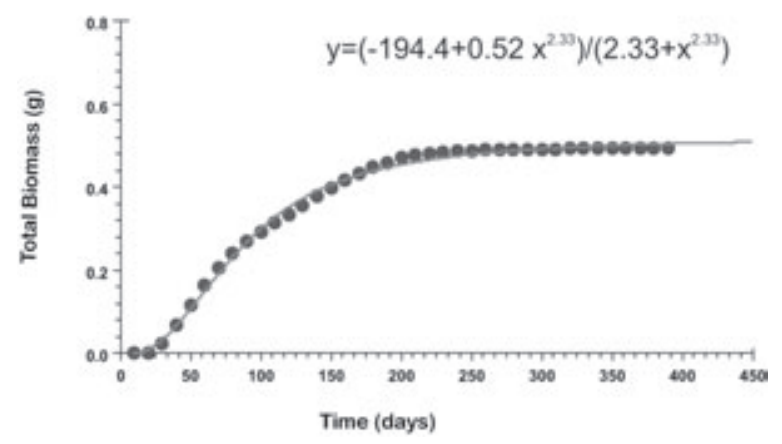

Figure 3. Model fitted to the increase of biomass of Azolla filiculoides through time. Modelo ajustado al incremento en biomasa de Azolla filiculoides a lo largo del tiempo. under unconstrained environmental conditions, produces new individuals with a final biomass of $0.4990 \mathrm{~g}$ in one year.

\section{DISCUSSION}

$\mathrm{AF}$ is recognised as an invasive alien plant (Sheppard et al., 2006) and fragmentation is the most likely cause of its explosive spread (Sculthorpe, 1967; Wagner, 1997).

The results obtained from the sigmoidal function model demonstrate that AF shows a high potential for clonal reproduction in the absence of environmental constraints (the final biomass obtained by shoot fragmentation is multiplied by 100 in one year). The large number of propagules obtained by shoot fragmentation enhances dispersion (Grace, 1993), facilitates the colonisation of new areas and maximises gene flow between populations; thus, providing enough genetic variability between localities (Barret et al., 1993).

According to others authors, floating macrophytes (Lemnaceae: Lemna spp., Spirodella spp., Wolffia spp., Table 2) have a lifespan of approximately 30 days (Ashby et al., 1949; Lemon et $a l ., 2001$ ), which is much lower than the lifespan observed for AF [initial individuals stayed alive throughout the experiment (215 days) and the mortality rate of propagules was very low (almost $1.60 \pm 0.71 \%$ of the total number of propagules produced)]. Lemon et al., (2001) found the mul- 
Table 2. Summary of values for the lifespan, number of propagules and fragmentation rate of different floating macrophytes. Resumen de diferentes valores de esperanza de vida, numero de propágulos producidos y tasa de fragmentación para diferentes especies de macrófitos flotantes.

\begin{tabular}{ccccc}
\hline Especies & Lifespan (days) & No Propagules & Fragmentation Rate & Reference \\
\hline Salvinia auriculata & - & 46 to 281 & - & Coelho et al., 2005 \\
Wolffia borealis & $15.8 \pm 1.5$ & $9.8 \pm 0.7$ & $0.62 \pm 0.03$ & Lemon et al., 2001 \\
Lemna minor & $31.3 \pm 1.1$ & $14.0 \pm 0.5$ & $0.45 \pm 0.02$ & Lemon et al., 2001 \\
Sphyrodela polyrhiza & $12.1 \pm 1.1$ & $1.1 \pm 0.5$ & $0.08 \pm 0.02$ & Lemon et al., 2001 \\
Lemna minor & 35 to 42 & - & - & Ashby et al., 1949 \\
\hline
\end{tabular}

tiplying strategy of macrophytes to be influenced by the life expectancy of mother-plants and an individual's potential to make propagules. Accordingly, our results are useful in understanding Azolla's life history strategy. The high longevity of mother-plants, together with the species' high ability to produce propagules by shoot fragmentation, represents an adaptive advantage that facilitates the success of colonisation by clonal reproduction.

However, in the absence of environmental constraints, the total and maximum number of propagules and the fragmentation rate varied through time. At the start of the experiment, we obtained a high number of propagules, but this number decreased progressively until the end of the experiment. These results are related to the aging of individual's within the population through time, as well as the effect clonal reproduction has on a population's dynamics. Accordingly, high levels of clonal recruitment in populations, where sexual recruitment is inhibited, are expected to strongly influence genetic variation within and among populations (Eckert, 2002). In this situation, individuals would lose the adaptive capability to face environmental variations (Eckert \& Barret, 1992).

Finally, the Azolla individuals used in our experiment came from Doñana temporary wetlands. This place represents a "new habitat" with environmental features quite different than Azolla's native ecosystems (Galán de Mera et al., 2006). The most apparent difference is the existence of a summer drought period each year (Díaz-Paniagua et al., 2010). Such characteristics could enhance the presence of specific ecotypes adapted and restricted to the environmental characteristics of the Doñana ecosystem. In this adaptation process, the symbiotic prokaryotic
Azolla's community plays a key role when facing new environmental stress conditions (Carrapiço, 2002, 2010). Sexual reproduction seems to be the best option to ensure a population's resistance after drought periods. Thus, further research on the Azolla-anabaena system and the sexual reproductive strategies of Azolla filiculoides in temporary habitats should be developed.

\section{ACKNOWLEDGEMENTS}

We are grateful to Laura Gonzalez-Guzman from the University of Texas at Austin for reviewing the English language and syntax.

This study was funded by the Spanish Ministry of Science and Education and EU FEDER funds (CGL2009-09801), the National Park Funding and the Spanish Ministry of Environment, Agriculture and Marine (158/2010). R.F.Z. holds a fellowship grant from the Andalusian Regional Government (2003).

\section{REFERENCES}

ALPERT, P., E. BONE \& C. HOLZAPFEL. 2000. Invasiveness, invasibility and the role of environmental stress in the spread of non-native plants. Perspectives in Plant Ecology, Evolution and Systematics, 3: 52-66.

ASHBY, E., E. WANGERMANN \& E. J. WINTER. 1949. Studies in the morphogenesis of leaves III. Preliminary observations on vegetative growth in Lemna minor. New Phytologist, 48: 374-381.

BARRET, S. C. H., C. G. ECKERT \& B. C. HUSBAND. 1993. Evolutionary processes in aquatic plant populations. Aquatic Botany, 44: 105-145. 
CARRAPIÇO, F. 2002. The Azolla-AnabaenaBacteria system as a natural microcosm. Proceedings of SPIEF 4495: 261-265.

CARRAPIÇO, F. 2010. Azolla as superorganism. Its implication in symbiotic studies. Celular Origin, Life in Extreme Habitats and Astrobiology 17: 225-241.

CARY, P. R. \& P. G. J. WEERTS. 1992. Growth and nutrient composition of Azolla pinnata $\mathrm{R}$. Brown and Azolla filiculoides Lammark as affected by water temperature, nitrogen and phosphorus supply, light intensity and pH. Aquatic Botany, 43: 163 180.

CIRUJANO, S., P. GARCÍA-MURILLO, R. FERNÁNḊEZ-ZAMUDIO, J. M. ESPINAR, A. RUBIO, A. MECO, I. LÓPEZ-BRAVO, R. SÁNCHEZ-ANDRÉS, S. SÁNCHEZ-CARRILLO, M. MORENO \& A. SOUSA. 2008. Estudio y control del helecho acuático invasor Azolla filiculoides en los humedales del Parque Nacional de Doñana 2005-2008 (Technical report). Royal Botanic Garden of Madrid (CSIC). Madrid, Spain.

COELHO, F. F., LOPES, F. S., SPERBER, C. F. 2005. Persistence strategy of Salvinia auriculata Aublet in temporary ponds of Southern Pantanal, Brazil. Aquatic Botany 81: 343-352.

DÍAZ-PANIAGUA, C., R. FERNÁNDEZ-ZAMUDIO, M. FLORENCIO, P. GARCÍA-MURILLO, C. GÓMEZ-RODRÍGUEZ, A. PORTHEAULT, L. SERRANO \& P. SILJESTROM. 2010. Temporary ponds from Doñana National Park: a system of natural habitats for the preservation of aquatic flora and fauna. Limnetica, 29: 41-58.

ECKERT, C. G. 2002. The loss of sex in clonal plants. Evolutionary Ecology, 15: 501-520.

ECKERT, C. G. \& S. C. H. BARRETT. 1992. Stochastic loss of style morphs from populations of tristylous Lythrum salicaria and Decodon verticillatus (Lythraceae). Evolution, 46: 1014-1029.

ECKERT, C. G., K. LUI, K. BRONSON, P. CORRADINI \& A. BRUNEAU. 2003. Population genetic consequences of extreme variation in sexual and clonal reproduction in an aquatic plant. Molecular Ecology, 12: 331-344.

GALÁN DE MERA, A., A. GONZÁLEZ, R. MORALES, B. OLTRA \& J. A. VICENTE ORELLANA. 2006. Datos sobre la vegetación de los llanos occidentales del Orinoco (Venezuela). Acta Botánica Malacitana, 31: 97-129.

GARBEY, C., G. THIÉBAUT \& S. MULLER. 2004. Morphological plasticity of a spreading aquatic macrophyte, Ranunculus peltatus, in response to environmental variables. Plant Ecology, 173: 125137.

GARCÍA-MURILLO, P., R. FERNÁNDEZ-ZAMUDIO, S. CIRUJANO, A. SOUSA \& J. M. ESPINAR. 2007. The invasion of Doñana National Park (SW Spain) by the mosquito fern (Azolla filiculoides Lam). Limnetica, 26: 243-250.

GARCÍA-NOVO, F. \& C. MARÍN. (EDS.). 2006. Doñana. Water and biosphere. Confederación Hidrográfica del Guadalquivir y Ministerio de Medio Ambiente. Madrid. Spain.

GRACE, J. B. 1993. The adaptive significance of clonal reproduction in angiosperms: an aquatic perspective. Aquatic Botany, 44: 159-180.

HONNAY, O. \& B. BOSSUYT. 2005. Prolonged clonal growth: escape route or route to extintion? Oikos, 108: 427-432.

JANES, R. A., J. W. EATON \& K. HARDWICK. 1996. The effects of floating mats of Azolla filiculoides Lam. and Lemna minor Kunth on the growth of submerged macrophytes. Hydrobiologia, 340: 23-26.

KOLAR, C. S. \& D. M. LODGE. 2001. Progress in invasion biology: predicting invaders. Trends in Ecology and Evolution, 16: 199-204.

LANDOLT, L. 1999. Pleustonic communities with Lemnaceae in South America Applied Vegetation Science, 2: 7-16.

LEMON, G. D., U. POSLUSZNY \& B. C. HUSBAND. 2001. Potential and realized rates of vegetative reproduction in Spirodela polyrhiza, Lemna minor and Wolffia borealis. Aquatic Botany, 70: $79-87$.

RAI, V., N. V. SHARMA \& A. K. RAI. 2006. Growth and cellular ion content of a salt sensitive symbiotic system Azolla pinnata-Anabaena azollae under $\mathrm{NaCl}$ stress. Journal of Plant Physiology, 163: 937-944.

SCULTHORPE, D. 1967. The biology of aquatic vascular plants. Edward Amold Ltd., London. UK.

SHEPPARD, A. W., R. H. SHAW \& R. SFORZA. 2006. Top 20 environmental weeds for classical biological control in Europe: a review of opportunities, regulations and other barriers to adoption. Weed Research, 46: 93-117.

STATSOFT INC. 2001. STATISTICA (data analysis software system), version 6. Statsoft, http://www. statsoft.com.

WAGNER, G. M. 1997. Azolla: a review of its biology and utilization. The Botanical Review, 63: 1-26. 
WETZEL, R. G. 2005. Invasive plants: the process within wetland ecosystems. In: Invasive Plants: Ecological and Agricultural Aspects. Inderjit (ed): 115-118. Birkhäuser, Germany.
XIAO, K., D. YU \& Z. WU. 2007. Differential effects of water depth and sediment type on clonal growth of the submersed macrophyte Vallisneria natans. Hydrobiologia, 589: 265-272. 
